Marvin L. Scilken, 330 W. 28th St., New York, NY 10001 .

Ted P. Sheldon, Director, University of Missouri Library, Kansas City.

Louise S. Sherby, Assistant Director for Public Services, University of Missouri, Kansas City.
Charles Townley, Head, Heindel Library, Pennsylvania State University, Middletown.

John Tyson, University Librarian, University of Richmond, Virginia.

James F. Williams II, Director, University of Colorado Library, Boulder.

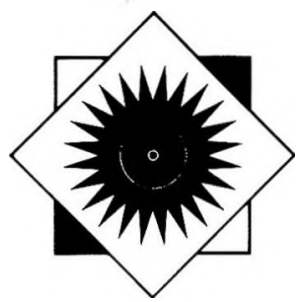

INNOVATIONS

\title{
Cavalry to the rescue: The use of temporary employees in place of student assistants
}

\author{
By Curtis L. Kendrick \\ Head, Circulation Department \\ State University of New York at Stony Brook
}

A persistent problem facing many academic libraries is the shortage of student assistants available to work during the winter intersession period. At the State University of New York at Stony Brook, this problem has been in evidence for years, resulting in shelving backlogs that can linger on well into the next semester. In order to combat this situation, this past intersession the library experimented with the use of temporary employees hired through an external agency.

In December 1987 the Head of Circulation approached the Associate Director for Reader Services, Planning, and Facilities with a proposal to hire full-time temporary employees through Manpower, Inc., a temporary employee service. Stony Brook has an arrangement with Manpower whereby employees can be hired at a discounted rate. The duties of the temporary employees were to be essentially shelving and shelf reading. Later in December the proposal was approved by Library Administration, and forwarded to the Office of the Provost for action. As planned, the library would hire four employees for four weeks, at a cost of approximately $\$ 3,500$ (the actual cost ended up being somewhat less, about $\$ 2,200$, as not all of the allocated hours were worked by the temporary employees).
The concept of using temporary employees in libraries is not new. Chervinko reported that $80 \%$ of the respondents $(n=74)$ to an Association of Research Libraries survey had hired temporary workers for a variety of projects. Only six of these libraries, however, reported that they had gone through an outside agency, and for the most part, the use of temporary employees has been for highlevel work such as cataloging, retrospective conversion, book selection, and bibliographic searching. ${ }^{1}$

Shortly before the program was to begin, Manpower contacted the library with the names of the employees who were scheduled to work. The library played no role in the selection of the employees, which could have been a drawback to this venture. Fortunately, the people that were sent over were capable and bright. All of the temporary employees were currently enrolled in college elsewhere. As students, they were familiar with academic libraries, and caught on quickly to the tasks they were required to perform.

\footnotetext{
${ }^{1}$ James S. Chervinko, “Temporary Employees in Academic and Research Libraries," Journal of Academic Librarianship 12 (September 1986):217-20.
} 
The level of training provided to these employees was minimal. It was felt that the reason for hiring them was to get work out of them in the short run, not to mold them into excellent workers. They were provided with a brief description of how books are arranged according to the Library of Congress system, given a short test to ensure their comprehension of this, and then turned loose on the shelving. Later on, they were given some additional instructions to learn how to shelf read. Daily supervision and work assignments became the responsibility of the Stacks Supervisor, a full-time clerical staff person.

Manpower displayed an interest in the performance of their people. After the first week an evaluation form was sent for each person. Factors upon which the employees were evaluated included attendance, work habits, and appearance. Because of the short duration of this project, it was necessary to make quick judgments about whether or not each of the employees was going to be adequate. One of the employees had to be fired after the third day due to an attendance problem. Manpower was notified about the problem, and sent a replacement the next day.

The results of this experiment were satisfactory. The shelving was done quickly and in time for the start of second semester. A portion of the collection was shelf read. Manpower was able to supply the library with competent employees on very short notice. The most significant problem was that towards the end of the project several of the workers had to quit to go back to school. By this time Manpower's labor pool had dwindled so they were not able to provide replacements.

The overall level of ability and effort displayed by the Manpower employees was on a par with that of the student assistants who work in the library. The cost was somewhat higher than it would have been to hire student assistants, but as there were not enough student assistants available, the point is moot. The use of temporary employees in lieu of student assistants will certainly be considered in the future for tasks such as shelving, shelfreading or shifting.

\section{Humor and creativity: Music}

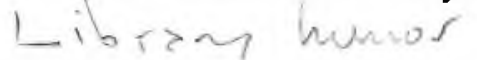

\section{By Norman D. Stevens}

\section{Director}

The Molesworth Institute
The many examples of library humor that I have collected over a number of years, including the many recent examples contributed by readers of these columns, demonstrate that music librarians, as I have long suspected for other reasons, are among the most creative and the most peculiar of all librarians. Perhaps I can now, at last, reveal that fact since I have recently been appointed, upon payment of the usual fee, Conductor of $\mathrm{Li}$ braries In Absentia at the North American School for the Artsy and Somewhat Musically Inclined in White Bear Lake, Minnesota.

The true reasons for this phenomenon remain a mystery but we can freely speculate about those reasons. It may be that, as sometimes frustrated and sometimes practicing musicians, music librarians share the creative traits associated with musicians and other artists that give them a broader imaginative scope than other librarians. Whoever heard of a funny chemist or chemistry librarian? Part of that creativity, of course, may be associated - as I will demonstrate below - with the right brain/left brain concept. Music librarians, so to speak, have a foot in both camps. Perhaps it may also be that their isolation from the mainstream of librarianship, and often from contact with other librarians on their own campus, as they work in remote and isolated branch libraries, drives them stir crazy or unleashes their imagination. Whatever the reason, it is clear that there is a great deal of entertainment to be found in their humor that deserves to be shared with a wider audience and not confined, as it so often has been, to their own kind.

In an earlier column on holidays (November 1988) I commented on the 1976 performance of The Salutation Army Band at the University of Illinois Library as a minor, and tame, example of music and library humor that involved both commentary and performance. That was, indeed, a mild case.

Bad puns seem to be among the most frequent themes of bad music library humor. That is exemplified by what were originally hand-lettered signs, which have now been replaced by more permanent professional signs, on the five listening rooms in the Greer Music Library at Connecticut College. Those rooms are named: John's Cage; The Nutcracker Suite; The Liszt-ning Room; The Haydn Place; and The Bach Room. Still, those puns seem harmless in comparison with those re- 